\title{
Organisational culture and TQM implementation: investigating the mediating influences of multidimensional employee readiness for change
}

\begin{abstract}
Despite the robust evidence for the direct relationship between organisational culture (OC) and total quality management (TQM), the mechanisms underlying this relationship are not fully explored and have received little empirical attention. This paper extends prior TQM research in a novel way by building and then empirically testing a theoretical model that includes the mediating role of employee readiness for change dimensions (ERFCs) in the OC-TQM relationship. The paper adds value through its contextual originality in being one of the first studies that are conducted in Algeria; which has special ties with the EU geographically, politically and economically. The empirical data for this study was drawn by distributing a questionnaire to 226 middle managers of Algerian firms. Our findings support the mediating roles of two dimensions of ERFC, namely: self-efficacy (ERFC1) and personal valence (ERFC4) in the OC-TQM relationship. This indicates that the improvement in TQM implementation is not a direct consequence of supportive organisational culture but rather of self-efficacy and personal valence transferring the impact of group and adhocracy culture to TQM. To this effect, these results go beyond previous research and contribute significantly in explaining the underlying psychological mechanisms in the OC-TQM relationships model.
\end{abstract}

Keywords: TQM, organisational culture, employee readiness for change. 


\section{Introduction}

In today's era of intense competition and globalisation, firms have been under increasing pressure to achieving and sustaining operational excellence in order to improve their overall performance and competitiveness (Eskildsen \& Edgeman, 2012; Kirkhama, Garza-Reyesb, Kumarc \& Antony, 2014). Organisations all over the world are grappling with changes in market conditions, technological innovations, political and economic uncertainties, and increased focus on customer and quality (Maheshwari \& Vohra, 2015). Firms are now, more than any other time, continuously faced with the need to adopt and embrace various global transformational initiatives such as quality management system and effective quality improvement programmes, in order to survive in this dynamic environment (Psomasa \& Antony, 2015; Valmohammadi \& Roshanzamir, 2015).

Total quality management (TQM) is one of the most significant evolutions of management practices for managing business effectively. To this effect, TQM has become one of the popular business strategies in numerous leading manufacturing industries over the last three decades (Sohal \& Terzivski, 2000; Georgiev \& Ohtaki, 2016). Many organisations all over the world have implemented TQM as a tool to produce higher-quality products that conform to the international quality awards criteria and standards (Albaum \& Duerr, 2008). This has positively resulted in an increased global market share, higher profits and better financial performance (Santos-Vijande \& Alvarez-Gonzalez, 2007).

The improvement, however, was not uniform across all organisations. Many organisations that adopted TQM for various reasons still struggle from chronic and rather serious quality challenges that have inevitably exacerbated poor quality causing considerable profit losses (Sila, 2007; Srinivasan \& Kurey, 2014). Indeed, enterprises with ineffectively developed quality cultures have been reported to spend on average $£ 250$ million more than organisations with effective quality culture (Srinivasan \& Kurey, 2014). Empirical research 
investigating the relationship between organisational culture (OC) types and TQM dates back to the 1990s ( $c f$. Chang \& Wiebe, 1996; Dellana \& Hauser, 1999; Al-Kalifa \& Aspinwall, 2001) and has flourished since then. Yet, the search for an improved understanding of OCTQM relationship continues.

The argument for the effects of OC on the implementation of TQM are compelling and well established in extant literature indicating a robust evidence for the positive relationships between TQM and particular OC types (Zu, Robbins \& Fredendall, 2010; Baird, Hu \& Reeve, 2011; Green, 2012; Gimenez-Espin, Jiménez-Jiménez \& Martínez-Costa, 2013). However, a deeper inspection and thorough analysis of the literature suggests that the arguments implicitly presume a possible role for employee readiness for change dimensions (ERFCs), as mechanisms through which TQM is associated with different OC types. That is, OC types influence TQM implementation indirectly through their impact on ERFCs. To this effect, a few recent research studies, mostly conceptual, have paid attention to the influence of OC on ERFC (Choi \& Ruona, 2011). Nevertheless, there are limited empirical studies that have examined the impact of OC types on ERFC. Also, recent and mostly conceptual studies indicate that there is an increasing recognition of the influence of ERFC (Weeks, Helms \& Ettkin, 1995; McNabb \& Sepic, 1995; Shea \& Howell, 1998; Meirovich, Galante \& Yaniv, 2006) on the success or failure of TQM implementation.

Simultaneously, much of the extant research studies treated ERFC as a unidimensional construct (Jones, Jimmieson \& Griffiths, 2005), and only limited attention has been given to the various dimensions of ERFC that have been developed by Holt, Armenakis, Field, \& Harris (2007). The authors were the first to treat ERFC as a multidimensional construct that distinguishes between four separate components where the weight and relevance of each of the ERFC components depend on the type of change that an organisation faces. The complexity of the relationship between ERFC components and TQM 
implementation has been less explored in a more comprehensive way to provide a sufficient understanding of the ERFC-TQM implementation relationship. We propose that more comprehensive research should be conducted to investigate the different influences of the four dimensions of ERFC and how they contribute in different ways to the level of TQM implementation. This would provide a deeper understanding of the ERFCs-TQM relationship and thus increases the likelihood of successful TQM implementation by paying extra attention to the significant components of ERFC dimensions.

Despite earlier calls for an investigation into the indirect relationship between OC and TQM, little has been done to attend to this call. Holbert and Stephenson (2002) stressed the need for research studies to move ahead of analysing direct influences since only by analysing the direct and indirect effects, better understanding on issues could be gained. This paper advances the extant TQM literature by reporting in a novel way the results of an extensive empirical research investigating the mediating effect of ERFC four dimensions on the relationship between OC and TQM implementation. This helps in determining the most important factors (ERFC components) that organisations should essentially take into account in order to increase the level of the TQM implementation's success. Moreover, understanding the complex relationship among TQM, individual readiness and OC helps to provide sound managerial practice to improve the success of TQM implementation.

The paper also adds value through contextual originality by being one of the first studies conducted in the Algerian context. Many Algerian manufacturing organisations (AMOs) have introduced and implemented TQM practices including continuous quality improvement, customer focus, total employee involvement in improving quality, supplier quality management, process management quality, and quality tools training (Kasemi, 2009; European Commission, 2013). However, the results of a few small scale studies indicate a low level of TQM implementation in AMOs (Kasemi, 2009). A 
comprehensive and critical review of the literature reveals a serious lack of empirical studies on the relationship between OC, ERFC dimensions and TQM implementation in the Algerian context. This study, therefore, provides breadth and an in-depth understanding of the relationship between OC, TQM, and ERFCs, particularly in AMOs hence contributing to the scarce body of literature about the North African countries.

\section{The issue of causality between organisational culture and TQM}

The extensive review of the literature revealed that despite the fact that there are various different definitions of the term 'organisational culture' (OC), the majority of these definitions include the idea of a mixture of beliefs, values and practices that are shared and perceived by organisational members as a guide for suitable actions in day-to-day work (Schneider \& Barbera, 2014). However, the majority of scholars on quality management initiative have traditionally paid more attention to the visible practices (artifacts) employed rather than the beliefs and values that support or hinder the new behaviours (Detert, Schroeder, \& Mauriel, 2000). Hence, in this paper, we focus on OC as " $a$ system of shared values defining what is important, and norms, defining appropriate attitudes and behaviours, that guide members' attitudes and behaviours" (O'Reilly \& Chatman, 1996: 160).

While many authors consider that TQM implementation leads to a change in OC, it has been argued by many other scholars such as Prajogo \& McDermott (2005), Zu et al. (2010) and Baird et al. (2011), that the implementation of TQM is affected by the OC, rather than the other way around. This study takes the viewpoint that OC precedes and influences TQM practices and that OC can function as a driver, 'fertile soil' or a barrier to the implementation of TQM.

Recent literature in the field of TQM shows that there is an increasing recognition of the influence of four OC types of the Competing Values Framework (CVF) on the success or 
failure of TQM implementations (Zu et al., 2010; Baird et al., 2011; Haffar, Al-Karaghouli \& Ghoneim, 2013). Many studies have examined the influence of the four culture types of CVF model and its matched scale (OCAI), namely group, adhocracy, hierarchical and market/rational cultures, on the implementation of TQM practices (e.g. Dellana \& Hauser, 1999; Al-Khalifa \& Aspinwall, 2001; Prajogo \& McDermott, 2005; Gimenez-Espin et al., 2013).

Cameron \& Quinn (1999) argued that organisations dominated by the adhocracy culture type are characterised by vibrant, innovative and flexible tendencies. Such culture tends to boost employees' initiatives and the implementation of new ideas and programmes such as TQM to improve the efficiency of their organisation (Al-Khalifa \& Aspinwall, 2001; Baird et al., 2011; Gimenez-Espin et al., 2013). The literature appears to support the positive influences of adhocracy culture on TQM implementation, and, therefore, the following hypothesis is posited:

H1. An organisation's emphasis on the adhocracy culture will be positively associated with the level of implementation of TQM practices.

The existing literature shows that scholars have different views on the influence of hierarchy culture on TQM implementation. A few authors such as Germain \& Spears (1999) believe that hierarchical culture can promote TQM implementation within the organisations. They posit that since organisations dominated by hierarchy culture emphasise close control, preventive maintenance, standardised rules and procedures governing the organisation, it could facilitate transmitting knowledge about TQM and ensure consistency of its implementation (Germain \& Spears 1999; Zu et al., 2010). However, the majority of previous research studies such as Dellana \& Hauser (1999) and Gimenez-Espin et al. (2013) have contradicted such findings. They conclude that that hierarchy culture characterised by high bureaucracy, lack of customer orientation and continuous improvement, has a negative 
impact on TQM implementation. According to Gimenez-Espin et al. (2013), employees who work according to fixed rules have limited opportunities to innovate, thereby, achieve continuous improvement and enhanced customer satisfaction, which is embodied in TQM. As a consequence, the following hypothesis was formulated:

H2. An organisation's emphasis on the hierarchy culture will be negatively associated with the level of implementation of TQM practices.

According to Cameron and Quinn (1999, p.58): "an organization dominated by group culture emphasizes the long-term benefit of human resources development (e.g. training) and attaches great importance to cohesion and morale." These organisations value teamwork, cohesion, employee involvement and human resource development that are inherited in TQM approach (Chang \& Wiebe, 1996; Al-Khalifa \& Aspinwall, 2001). To this effect, group culture is considered to be the most supportive culture type for successful implementation of TQM (Baird et al., 2011; Gimenez-Espin et al., 2013). It is, therefore, reasonable to put forward the following hypothesis:

H3. An organisation's emphasis on the group culture will be positively associated with the level of implementation of TQM practices.

On the other hand, while a few authors such as Prajogo \& McDermott (2005) have argued that market culture may support the implementation of TQM, the findings of the majority of previous studies such as Chang \& Wiebe (1996) and Gimenez-Espin et al. (2012) have indicated that organisations dominated by a market culture suffer from weak and troublesome TQM implementation. This is due to the top management being result-orientated whose major concern is with getting the job done (Cameron \& Quinn, 1999). The question of morale and personnel development tends to be less important to the leaders of such organisations (Cameron \& Quinn 1999; Zammuto et al. 2000). Consequently, organisational 
members are less likely to successfully implement TQM. Thus, this study proposes the following hypothesis:

H4. An organisation's emphasis on the market culture will be negatively associated with the level of implementation of TQM practices.

\section{The mediating effects of multidimensional employee readiness for change}

It is widely known that employees' beliefs influence the cognitive process in which they engage to decide whether or not to implement new practices. As a consequence, companies accept or refuse change through the actions of their employees (Armenakis, Harris \& Mossholder, 1993; Armenakis et al., 1999). ERFC dimensions have been recently considered to be key factors in achieving change implementation success in the workplace (Jones et al., 2005; Holt et al., 2007; Herold, Fedor \& Caldwell, 2007; Choi \& Ruona, 2011).

The most widely cited definition of employees readiness was offered by Armenakis et al. (1993), who defined ERFC as an employee's “beliefs, attitudes, and intentions regarding the extent to which changes are needed and the organisation's capacity to successfully undertake those changes" (p. 681). Although the subsequent definitions of ERFC term, used in management literature, vary from one scholar to another (see Table 1), it is clear that various definitions of ERFC are principally derived from Armenakis et al.'s original work.

\section{Table 1 here}

Whilst many researchers such as Armenakis et al. (1993) and Jones et al. (2005) assessed ERFC as a one-dimensional construct, the recent findings of Holt et al. (2007) indicated that ERFC should be treated as a multidimensional construct that consists of four components: change specific efficacy, personal benefit of the change, management support for the change and change appropriateness (see table 2). 


\section{Table 2 here}

The importance of the state of employee readiness as a necessary condition to the successful implementation of TQM has been tackled by many researchers. More specifically, scholars such as Weeks et al. (1995), Shea and Howell (1998) and Meirovich et al. (2006) conducted research focusing on employees readiness where they found that ERFC is positively correlated with successful implementation of TQM as employees were more engaged in the process. Meirovich et al. (2006) in their research showed clearly that when employees are not eager, the likelihood of TQM failure increases.

Authors such as Case and Srikatiana (1998) believe that organisational members' perception of the relevance of TQM practices to improving organisational performance has a positive influence on their willingness to accept the implementation of TQM. Choi, Kim \& Yoo (2016) argued that when organisations establish the importance of effective TQM implementation as a shared vision and goal, their employees will endeavour to pursue TQM with a common aspiration. Therefore, based on the foregoing, we propose the following hypothesis:

H5. Organisational members' perceptions of change appropriateness will be positively related to TQM implementation success.

Employees who have received adequate training on TQM implementation will have more confidence in their ability to cope with TQM practices effectively, and their eagerness to accept and support TQM implementation should be high (Weeks et al., 1995; Shea \& Howell, 1998; Ingelsson, Eriksson \& Lilja, 2012). This will, in turn, foster individuals' involvement in the implementation of TQM and increase the probability of TQM success (Shea \& Howell, 1998; Harvey \& Millett, 1999; Soltani, Lai \& Gharneh, 2005). Such extant studies suggest that the level of organisational members' self-efficacy has a positive influence 
on the level of TQM implementation success. Based on the above, the following hypothesis is formulated:

H6. Organisational members' self-efficacy perceptions will be positively related to TQM implementation success.

It is argued by Weeks et al. (1995) that in order to enhance the likelihood of TQM success, an organisation's top decision makers should put all of their support behind the implementation of TQM (ERFC- management support). In contrast, Bokamkm \& Bedisi (2007) found that low level of top management support has contributed to the low level of TQM implementation in Algerian Manufacturing Organisations (AMOs). By committing to TQM, top management should support employees' development and involve them in the process of TQM implementation (Choi et al., 2016). This will lead to increased employees' acceptance of TQM implementation. As a consequence, the following hypothesis was developed:

H7. Organisational members' perceptions of management support will be positively related to TQM implementation success.

In order for change initiatives, such as one introduced via TQM implementation to be achievable, organisational members need to be convinced that they will gain some benefits (ERFC- personal valence) as a result of their participation in achieving TQM implementation success, such as promotional opportunities or rewards (Shea \& Howell, 1998). This, in turn, leads them to behave in a manner consistent with TQM principles (Weeks et al., 1995; Shea \& Howell, 1998). Moreover, when employees believe that they will not lose their status and their jobs will not be limited because of TQM implementation, their readiness to accept a new managerial approach, such as TQM, is more likely to be high (Whetten \& Cameron, 1991; Weeks et al., 1995; Whetten, Cameron \& Woods, 2000). It is, therefore, reasonable to put forward the following hypothesis: 
H8. Organisational members' perceptions of personal benefits will be positively related to TQM implementation success.

Even though ERFC dimensions are individual-level constructs, they require consideration of the organisational context (Jansen, 2000, ). Concentrating purely on ERFC, without taking into consideration the vital role of supportive OC, risk any readiness produced being unsustainable. Therefore, recent studies have paid attention to the influence of OC types on ERFC (Eby, Adams, Russell \& Gaby, 2000; Jones et al., 2005). However, empirical studies that have addressed the influence of all OC types on ERFC dimensions are scant.

Bureaucracy, complex rules, and processes with low flexibility are considered to be characteristics of hierarchy culture (Cameron \& Quinn, 1999). In such organisations, steadiness and rigid rules are emphasised and organisational members tend to avoid uncertainties as well as the risk associated with any change (Eby et al., 2000; Patterson et al., 2005). Interpersonal relations tend to demonstrate lower levels of trust and morale with higher levels of conflict and resistance to change (Zammuto, Gifford \& Goodman, 2000). Thus, we hypothesise that employee readiness for change will be reduced in organisations dominated by hierarchy culture.

H9. An organisation's emphasis on the hierarchy culture will be negatively associated with the level of ERFCs.

In contrast, organisations dominated by adhocracy culture that avoids hierarchy, stimulates individual initiatives and the utilisation of new systems such as effective quality improvement programmes. It is worth noting here the famous saying of the late Steve Jobs that organisations "have to be run by ideas, not by hierarchy". To this effect, organisations dominated by adhocracy culture rather than hierarchy culture values offer higher levels of ERFC (Zammuto \& Krakower, 1991; Zammuto \& O’Connor, 1992; Jones et al., 2005). Therefore, the following hypothesis was developed: 
H10. An organisation's emphasis on the adhocracy culture will be positively associated with the level of ERFCs.

It is argued by Cameron and Quinn (1999) that organisations dominated by the market culture have a result-driven ethos. The leaders focus on achieving the biggest market share with less confederating and caring of the morale and development of the human resources in the organization (Cameron \& Quinn, 1999; Zammuto et al., 2000). The employees in such organisations perceive any change as being mainly beneficial for the company's sake and could lead to a personal loss (Shum et al., 2008). Thus, we hypothesise:

H11. An organisation's emphasis on the market culture will be negatively associated with the level of ERFCs.

An organisation where group culture is the dominant values highly the importance of morale and pays a lot of attention to the critical role of employees' personal development and commitment (Cameron \& Quinn, 1999). As a consequence of such culture type, employees, in such organisations, exhibit a high level of readiness for accepting change and hence are more adept in implementing new processes because the dominant organisational offer them the confidence in themselves. In addition, organisation characterised by group culture is internal customer focused and attaches great importance to morale (Cameron \& Quinn, 1999). In such organisation, members believe that they will get benefits, including promotional opportunities or rewards, in return for their positive involvement in achieving a successful change implementation (Jones et al., 2005). Moreover, the findings of many research studies suggest that group culture has a positive influence on employee readiness for change (Jones et al., 2005; Vakola \& Nikolaou, 2005, Haffar, Al-Karaghouli \& Ghoneim, 2014). Therefore, we hypothesised:

H12. An organisation's emphasis on the group culture will be positively associated with the level of ERFCs. 
The previous 12 hypotheses show the relationships amongst OC types, ERFCs and TQM. Implicitly, the discussion suggests that OC types influence TQM through their impact on ERFCs. That is, OC types have an impact on the level of ERFCs, which, in turn, influences the level of TQM. This leads to the formulation of the following hypothesis:

H13. ERFC dimensions mediate the effect of organisational culture on TQM.

This main hypothesis is divided into the following sub-hypotheses ranging from $\mathrm{H} 13 \mathrm{a}$ to H13d investigating the mediating role of ERFC dimensions (a) self-efficacy, (b) appropriateness, (c) management support and (d) personal valence in the relationship between organisational culture types: group culture hierarchy, adhocracy and market culture and TQM.

H13a. Self-efficacy (ERFC1) mediates the effect of (a) group culture (b) hierarchy culture, (c) adhocracy culture and (d) market culture on TQM.

H13b. Appropriateness (ERFC2) mediates the effect of (a) group culture (b) hierarchy culture, (c) adhocracy culture and (d) market culture on TQM.

H13c. Management support (ERFC3) mediates the effect of (a) group culture (b) hierarchy culture, (c) adhocracy culture and (d) market culture on TQM.

H13d. Personal valence (ERFC4) mediates the effect of (a) group culture (b) hierarchy culture, (c) adhocracy culture and (d) market culture on TQM.

\section{The proposed theoretical framework}

Through the critical review, in-depth examinations and theoretical discussions mentioned in the previous sections, we developed a proposed theoretical framework (see Figure 1). Our integrative theoretical framework was developed by combining the direct effect of $\mathrm{OC}$ on TQM implementation and the indirect effect (through ERFCs) on TQM in a single model. 
This framework is constructed by integrating social cognitive theory (Shea \& Howell, 1998) with contingency theory (Sousa \& Voss, 2001; Sila, 2007; Zhao et al., 2004) to explain the relationship between OC types, ERFC dimensions and TQM. Drawing from these theories, this novel framework posits that the more supportive organisational culture types (causal variables), the higher employees' readiness for change and (intervening variables) will be and the higher their level of TQM implementation (outcome variable).

Firstly, underneath contingency theory premises is the assumption that organisational culture directly influences ERFC and TQM implementation. Secondly, based on the social cognitive theory premises, the model postulates that ERFC components (change specific efficacy, personal benefit of the change, management support for the change and change appropriateness) are positively related to TQM implementation. Shea \& Howell (1998) consider that there is a cognitive, self-regulatory mechanism which mediates the influence of situational factors on TQM consistent behaviours. This mediator is an internal and not directly observable psychological process, which transmits an effect from antecedent to a consequence (James \& Brett, 1984). As a consequence, and in accordance with social cognitive theory, the current study proposes that ERFC dimensions mediate the effects of organisational culture types on the level of TQM implementation.

According to the proposed model in this paper (see Figure 1), a distinction should be made between the components of individual readiness for change. This can be guided by the component factors (change specific efficacy, personal benefits of the change, management support for the change and change appropriateness) identified in this paper, based on the study of Holt et al. (2007). This would provide a deeper understanding of the relationships between ERFCs, TQM as well as OC. To the best knowledge of the authors, this is the first time such an integrative theoretical framework has been tested theoretically and empirically.

\section{Figure 1 here}




\section{Research instruments, Procedures, and Sampling}

The study does not aim to validate or develop new instruments to measure the level of implementation of TQM practices, OC profiles, and level of ERFC. Therefore, this research adopted and translated three widely used, valid and reliable instruments which fitted and served the aim and objectives of the current study.

In order to identify the cultural profile and characteristics of Algerian manufacturing organisations (AMOs), the OC assessment instrument scale called Organisational Culture Assessment instrument (OCAI) developed by Cameron and Quinn (1999) was used. Several studies have proved the reliability and validity of the CVF and its matched scale, OCAI (Alkhalifa \& Aspinwall, 2001; Yu \& Wu, 2009). In order to measure the level of implementation of TQM in AMOs manufacturing organisations, the instrument developed by Samson \& Terziovski (1999) was utilised and adopted. In this instrument, the empirical constructs are guided by and based on the principle criteria of the MBNQA. In order to measure the level of ERFC components, the reliable and valid instrument developed by Holt et al. (2007) was adopted. Unlike previous studies which treated ERFC as a onedimensional construct, Holt et al. (2007) developed a more precise and relevant measurement of ERFC. They treated it as a multifaceted measure that distinguishes between four components of ERFC namely (change specific efficacy, personal benefits of the change, management support for the change and change appropriateness). This current study also uses the scale of Holt et al. (2007), as it fully captures existing definitions and concepts of ERFC and offers better operationalisation of this variable. All the items were assessed via a five-point Likert-scale, ranging from 1 (strongly disagree) to 5 (strongly agree). 
The target population of this research consists of all the public and private Algerian manufacturing organisations (AMOs) involved in implementing quality initiatives. The population of AMOs is concentrated mostly in the South of Algeria and very few are located in the northern part which is mainly desert (part of the Grand Sahara). $70 \%$ of AMOs is based in two cities (Algiers and Oran). Contacting and distributing the questionnaires to all the relevant companies was difficult due to the geographical spread, thus, we chose to adopt a random sampling technique and selected a sample consisting of 226 out of 278 AMOs, involved in implementing quality initiatives. The sample covers a wide cross-section of manufacturing industries including, chemical, clothing, pharmaceuticals, food and electronics. Thus, the researcher aimed at selecting a random sample, as it is more likely to be representative of the population from which it has been selected. This in turns would enable the use of some statistical techniques to test the research hypotheses and enhance the generalisability of the findings.

As mentioned before, the three instruments have been used in many previous studies. After translating them to native language (Arabic), the measurement scales were reviewed by respective experts and academics from Algerian universities to assess face and content validity before the questionnaires were distributed to the target sample. All of the experts considered that the questionnaire was appropriate, would achieve the aim of the study and needed only a little editing. The proposed questionnaire was then adjusted and amended according to the feedback and comments of the experts. A personal delivery procedure of the questionnaires to the participants and the collection of the completed ones was adopted as it is considered the most efficient method of data collection in the Algerian context. The final version of the questionnaire was distributed to 226 middle managers (operation, production and quality managers) in AMOs. 
The middle manager deemed as most familiar with the topic in each organisation was approached to complete the questionnaire. This methodological approach has been used in previous studies (e.g. Goll \& Rasheed, 1997; Djebarni, 1996; Al-Hyari \& Djebarni, 2008) and had been found to be more successful. In the context of this research, middle managers were considered as the key participants that fit this bill. It is considered that middle managers are the key agents of change. In addition, they set up and launch the practices and incentives that are needed to maintain the change in their departments. TQM will not work if these middle managers do not have a comprehension of and commitment to TQM (Schneider et al., 1996). The completed questionnaires numbered 131,118 of which were useable. The overall response rate was thus $52.2 \%$. The sample size is deemed adequate based on the output of the statistical package G*Power 3 which was 108 with Power (1- $\beta$ error probability) of $90 \%$ and $\alpha$ of 0.05 effect size $f^{2}=0.15$. Moreover, many authors consider $100+$ to be a good sample size. For example, while Green (1991) suggested $N>50+8 \mathrm{~m}$ (where $\mathrm{m}$ is the number of IVs) for testing the multiple correlation and $N>104+\mathrm{m}$ for testing individual predictors (assuming a medium sized relationship); Tabachnick \& Fidell (2013) suggested that although 20 cases per variable would be preferable, the minimum required case per variable should be 5 .

\section{Data analysis and results}

Multiple linear regression analysis was conducted to effectively test the hypotheses. However, before testing our hypotheses, we have ensured that the reliability and validity were met (Djebarni, Burnett \& Richards, 2014). Principal components factor analysis was used for assessing the construct validity by measuring the indicator loadings (Hair, Black, Babin \& Anderson, 2010). There is no agreement in the literature about an appropriate loading value (Kline, 1994; Field, 2005; Tahbanik \& Fidell, 2013). Some studies such as 
Abdul-Halim and Che-Ha (2009) posit that items with loadings of 0.4 and higher indicates a reasonable and adequate loading. Meanwhile, Tabachnick and Fidell (2013) consider that items with factor loading over 0.32 should be retained for consequent analysis. Their conclusion is line with the advice of Kline (1994) who reports that 'factor loadings are moderately high if they are above 0.3 , the minimal accepted cut-off. The results presented in Table 3 show that the individual items were well loaded and related robustly to their respective factor. The percentage of total variance explained by all items under each construct factor was above $50 \%$. Therefore, this study concludes that all measures have acceptable construct validity and are of a unifactorial nature. Similar to the theoretical categorisation, each measure formed a 'solid' single construct and exhibited strong unidimensionality from a statistical perspective. These findings are consistent with several previous studies such as Ahire et al. (1996) and Santos-Vijande and Alvarez-Gonzalez (2007) that proclaimed a single factor to represent the TQM practices. Therefore, TQM is modelled as a single latent variable that is measured by six first-order latent variables, namely plan (Strategic Planning), info (Information and Analysis), peop (People Management), cust (Customer Focus), proc (Process Management) and lead (Leadership). Furthermore, we have computed the composite reliability (CR) for all measurement items. The CR values for all latent constructs were well above the benchmark of 0.6 as recommended by Bagozzi \& Yi (1988), which demonstrated satisfactory convergent validity. Cronbach's coefficient alpha is used to assess the reliability of scales and the degree of internal consistency. All Cronbach's alpha of the constructs exceeded the 0.7 threshold (Hair et al., 2010) ranging from 0.707 to 0.889 which indicate scale reliability (see Table 3 ).

\section{Table 3 here}


Table 4 illustrates the mean score for OC types, TQM implementation, and ERFC components. According to the mean values, it is clear that hierarchy and market culture types are dominant, the level of ERFC components and TQM implementation were low in AMOs.

\section{Table 4 here}

All the regression models tested met the validity requirements and no problem was detected. Thus, these models, which were generated from the sample, can be accurately applied to the population of interest (Hair et al., 2010). The variance inflation factor (VIF) values of the independent variables for all models is less than the maximum level of 10 and the Tolerance (TOL) value in all models is higher than the minimum level of 0.2. These statistics indicated no multicollinearity problem exist among the independent variables in all models. Thus, multicolinearity was not a problem (Hair et al., 2010). The regression models have a good explanatory power (adjusted $\mathrm{R}^{2}$ ) value of $.261, .226, .222, .206, .235, .332, .348$, and .354 respectively. The overall models tested were highly statistically significant (F-value significant on $1 \%$ level), which means all the reported models are reliable. As a consequence, the regression models provide an acceptable prediction of the dependent variables.

This study follows Baron and Kenny's (1986) procedure to examine the mediating role of ERFCs between OC and TQM. To establish the existence of this mediation effect, four conditions should hold: (1) the predictor (organisational culture types) variables should significantly influence the dependent variable (TQM). (2) The predictor variable (organisational culture types) should significantly influence the mediator variable (ERFCs); (3) the mediator should significantly influence the dependent variable (TQM); and (4) after we control for the mediator variable (ERFCs), the impact of the predictor (organisational culture types) on the dependent variable (TQM) should be reduced in strength (for partial mediation) or should no longer be significant (for full mediation). Thus, we first checked for 
the three prerequisite conditions before testing the mediation effects formulated in hypotheses $H 13(a, b, c$ and $d)$.

(1) Multiple regression analysis was used to test the direct influence of OC types on TQM. Overall, as shown in Table 5, adhocracy culture $(\beta=0.248, \mathrm{p}<0.005)$ and group culture $(\beta=0.301, \mathrm{p}<0.001)$ have a positive influence on TQM. These results lend support to $H 1$ and $H 3$. Thus, test the indirect effects of group and adhocracy culture types only meet Baron and Kenny's (1986) first test condition. However, the effect of market culture and hierarchy culture are not significant; thus, $\mathrm{H} 2$ and $\mathrm{H} 4$ are not supported and testing for mediation for these variables violates the first test condition.

(2) We tested the direct effects of OC types (independent variables) on ERFC components (mediator). As Table 5 shows, adhocracy culture $(\beta=0.191, \mathrm{p}<0.005)$ and group culture $(\beta=0.378, \mathrm{p}<0.001)$ have positive and significant effects on personal valence (ERFC4). Also, adhocracy culture $(\beta=0.164, \mathrm{p}<0.005)$ and group culture $(\beta=0.267, \mathrm{p}<$ 0.001) have positive and significant effects on self-efficacy (ERFC1). Similarly, adhocracy culture and group culture have positive and significant effects on management support (ERFC3) and appropriateness (ERFC2). These results strongly support the research hypotheses numbers $H 10$ and $H 12$. Thus, the condition for step 2 was met.

(3) We tested the influence of the ERFCs (mediators) on TQM (H5- H8). Our results demonstrated that the direct paths from two of ERFC components namely management support (ERFC3) and appropriateness (ERFC2) were not significant; thus, $H 5$ and $H 7$ are not supported. Whereas self-efficacy -ERFC1- $(\beta=0.431, \mathrm{p}<0.001)$ and personal valenceERFC4- $(\beta=0.239, \mathrm{p}<0.001)$ have a positive and significant effect on TQM implementation. These results strongly support the research hypotheses numbers $H 6$ and $H 8$. Thus, self-efficacy (ERFC1) and personal valence (ERFC4) met the condition for step 3. 
(4) We conducted multiple regression analysis to include the mediators in the models in order to assess the mediating role of ERFCs in the relationship between group culture/adhocracy culture and TQM. The inclusion of personal valence (ERFC4) into Models 7 leads to a decrease in the effect size (i.e. strength) of adhocracy culture (from $\beta=0.248$ to $\beta$ $=0.178$ ) and group culture (from $\beta=0.301$ to $\beta=0.241$ ) on TQM, but remain significant, suggesting partial mediation. Similarly, the inclusion of self-efficacy (ERFC1) into Model 8 leads to a decrease in the effect size (i.e. strength) of adhocracy culture (from $\beta=0.248$ to $\beta=$ 0.180) and group culture (from $\beta=0.301$ to $\beta=0.197$ ) on TQM, but remain significant, suggesting partial mediation. These findings show that adhocracy and group culture influence TQM implementation indirectly via their impacts on self-efficacy (ERFC1) and personal valence (ERFC4), in support of $H 13 a$ and $H 13 d$.

\section{Table 5 here}

\section{Discussion}

This research is set out to investigate the mediating effect of ERFC four dimensions on the relationship between $\mathrm{OC}$ and TQM implementation. A number of authors have found that group and adhocracy culture types are associated with higher levels of ERFC (Eby et al., 2000; Jones et al., 2005). Relatively similar findings have been found in manufacturing organisations in Algeria where adhocracy culture and group culture have positive and significant effects on TQM. In addition, while previous studies indicated that market culture was associated with lower levels of ERFC (Eby et al., 2000; Jones et al., 2005; Zammuto \& O’Connor, 1992; Zammuto \& Krakower, 1991), our findings suggested that market culture has a positive influence on two of the ERFC components namely management support (ERFC3) and appropriateness (ERFC2). In other words, organisational members who rate their OC as being high in market culture values perceive lower levels of management support 
(ERFC3) and appropriateness (ERFC2). This suggests that top management support for TQM would be low in these organisations as they are short term oriented whose aim is to achieve the biggest market share and profit in as short a time as possible, while they believe that the implementation of TQM practices could be costly and not feasible in a short term despite its potential to achieve competitive advantages in a long term. Thus, they did not make sufficient efforts to explain the positive influence of TQM implementation on the employees and the performance of their organisations.

Additionally, the empirical results show that different ERFC dimensions (ERFC-self efficacy, ERFC personal valence, ERFC- management support and ERFC- appropriateness) have different influences on TQM implementation. In particular, we found that two dimensions of ERFC, namely self-efficacy (ERFC1) and personal valence (ERFC4) have a positive influence on TQM implementation. Meanwhile, the other two dimensions of ERFC, that is management support (ERFC3) and appropriateness (ERFC2), have a negative influence on TQM. The results regarding appropriateness were in some way surprising. It was expected that organisational members who felt that TQM implementation is appropriate and beneficial for the organisation were more willing to involve TQM implementation more effectively. However, our hypothesis was not supported. Other authors have also found different results. Neves (2009) found that employees believe that change appropriateness has a significant and positive influence on change implementation. These diverse findings mean that the role of appropriateness on change-related variables (TQM practices) may depend on other contextual factors, such as the characteristics of the undergoing change, due to which these relationships would normally vary. It would appear that in a relatively low humane oriented organisational context as exemplified in Algeria, organisational members give less consideration for the value of change at the organisational level. This might be considered as a payback for the relatively poor organisational attention to employee wellbeing and welfare. 
Conversely, organisational members are more interested in rewards that are personally beneficial. In effect, they give more consideration to themselves than the organisation.

It is concluded that the weight and relevance of each of the ERFC components depend on the type of change that organisations face. It seems that organisational members in Algerian manufacturing organisations focus on what is expected of them, whether they are able to do it, what the consequences of change are and what they will gain as a result of their involvement in the TQM implementation. When the change focuses primarily on the implementation of new management systems such as TQM, the role of individual variables such as self-efficacy and personal valence is enhanced in the Algerian context. Conversely, the other dimensions of ERFC, namely appropriateness and management support, are decreased. In such situations, organisational members tend to focus on what is expected of them, whether they are able to do it (self-efficacy) and what the consequences of TQM implementation on themselves (personal valence) are. These findings have clearly shown that different ERFC components contribute in different ways to the level of TQM implementation.

The present results agree with previous research studies into the positive relationship between the group and adhocracy OC as antecedents of TQM (e.g. Dellna \& Hauser, 1994; Chang \& Wiebe, 1996; Al-Khalifa \& Aspinwall, 2001, Gimenez-Espin et al., 2013). However, in addition, we showed that this relationship is partially mediated by self-efficacy (ERFC1) and personal valence (ERFC4). Thus, group culture and adhocracy culture exert some of their influences on TQM implementation via self-efficacy (ERFC1) and personal valence (ERFC4) (as mediating variables), and they exert some of their influence directly and not via ERFC dimensions. These results extend previous research on predictors of TQM by showing empirically that self-efficacy (ERFC1) and personal valence (ERFC4) add good value to the explanation of TQM and helps improve the level of TQM in manufacturing 
organisations. Our research reveals that self-efficacy (ERFC1) and personal valence (ERFC4) canalise group and adhocracy culture impacts on TQM. This indicates that the improvement in TQM implementation is not a direct consequence of supportive organisational culture but rather of self-efficacy (ERFC1) and personal valence (ERFC4) transferring the impact of group and adhocracy culture to TQM.

\section{Theoretical contributions, managerial implications, and further research suggestions}

\section{Theoretical contributions}

This paper extends prior TQM research in a novel way by building and then empirically testing a theoretical model of the mediating role of employee readiness for change dimensions (ERFCs) in the OC-TQM relationship. Our findings indicate that the influence of organisational culture is, in fact, a sequential process affecting two of ERFC dimensions (self-efficacy and personal valence), and in turn, TQM. Hence, the relationship between OC and TQM can be better explained by incorporating the mediating roles of ERFC dimensions. Thus, it is concluded that the ERFC psychological mediators are useful for transmitting and enhancing the influence of OC (antecedent) on TQM implementation (consequence). To this effect, this paper offered novel evidence that helps improve theorising the mechanisms of the relationship between OC and TQM.

Additionally, the majority of previous studies had traditionally considered ERFC as a unidimensional construct and did not take into account the different components of ERFC (e.g. Armenakis, 1993; Jones et al., 2005). The present study, however, goes one step further by looking at ERFC as a multidimensional construct comprising self-efficacy, personal valence, management support and appropriateness based on the seminal study of Holt et al. (2007). To this effect, the empirical results show that different ERFC dimensions, which have been incorporated in this study, have different roles and relationships with OC types and TQM. Thus, our current research provides support to the findings of Holt et al. (2007), who 
treated ERFC as a multidimensional construct, and concludes that the components of individual readiness for change are distinguishable. Thus, this paper makes a significant contribution to the ERFC model by advancing an explanation as to how different ERFC components influence TQM implementation success. This provides insights and practical evidence to those managers who are willing to enhance the level of ERFCs and initiate TQM more effectively.

\section{Managerial implications}

In order to improve the rate of change implementation in Algerian manufacturing organization, managers must understand the sequence of the effects of organisational culture and make sure their employees are ready for change. Leaders need to realise that any style of management that is hierarchical or authoritative and low in human orientation is not conducive to successful implementation of TQM. The management should seek to create and sustain supportive group and adhocracy culture values, together with creating self-efficacy as well as personal valence, to improve TQM. In other words, they first need to create a supportive culture to serve as a fertile environment to prepare employees physiologically and minimise their resistance to change and subsequently prepare them to commit to TQM implementation.

AMOs should value teamwork, cohesion, employee involvement, human resource development, flexibility and creativity. The management of AMOs should also encourage their organisational members to get more involvement in TQM implementation by developing a fair incentive scheme and reward the members who contribute towards a successful TQM implementation. This leads to enhance of the members' feelings of personal benefits which result from participating in TQM implementation. This in turn leads them to behave in a manner consistent with TQM principles showing higher levels of involvement in TQM execution efforts. 


\section{Limitations and proposed future research}

Although the study objectives were accomplished, some limitations of the study should be noted. First, whilst structural equation modeling (SEM) might be an effective alternative method for analysing multivariate data, our study conducted multiple regression analysis (MRA) as an adequate tool for testing our hypotheses. Given that the total population was less than 300 and the completed usable questionnaires were 118, using SEM was not possible as it requires at least 200-400 respondents depending on different experts in the field. However, like many other studies such as Yang et al. (2010), the current study suggests that future research should verify our findings with a larger sample size, where the population is quite sizeable, in a different contexts using SEM.

Another limitation is that this study is grounded on the cross-sectional research design, which does not allow confirmatory causal explanations and limits the researchers' ability to tackle or refer to the change or the development of the relationship between the variables over a period of time. Future work should use longitudinal designs that allow for tracing possible changes and give clearer picture of the change process.

Lastly, the majority of the studies on the relationship between the research constructs have been conducted in manufacturing organisations. However, empirical studies in nonmanufacturing industries have been scarce (By, 2007). As developed countries have entered the post-industrial period, the focus on traditional manufacturing industries in change management studies forms an obvious gap in the research stream. Manufacturing accounts for $12.6 \%$ of the gross value added in the UK, $12.2 \%$ in the USA, $20.7 \%$ in Japan and $22.7 \%$ in Germany (OECD, 2012). Therefore, we suggest that future studies should address the dearth of scholarship about the relationships between OC, ERFC, and TQM in nonmanufacturing industries. 


\section{References}

Ahire, S.L., Golhar, D.Y. and Waller, M.W. (1996). Development and validation of TQM implementation constructs. Decision Sciences, 27 (1), 23-56

Al-Khalifa, K. N. and Aspinwall, E. M. (2001). Using the competing values framework to investigate the culture of Qatar industries. Total Quality Management, 12 (4), 417-428

Albaum, G. and Duerr, E. (2008). International Marketing and Export Management, $6^{\text {th }}$ ed., Pearson Education limited, England

Armenakis, A. A., Harris, S. G., and Mossholder, K. W. (1993). Creating readiness for organisational change. Human Relations, 46(6), 681-703

Baird, K., Jia Hu, K. and Reeve, R. (2011). The relationships between organisational culture, total quality management practices and operational performance. International Journal of Operations and Production Management, 31 (7), 789-814

Baron, R. and Kenny, D. A. (1986). The Moderator- Mediator Variable Distinction in Social Psychological Research: Conceptual, Strategic, and Statistical Considerations. Journal of Personality and Social Psychology, 51 (6), 1173-1182.

Bagozzi, R. and Yi, Y. (1988). On the Evaluation of Structural Evaluation Models. Journal of the Academy of Marketing Science, 16 (1), 74-94

Cameron, K. S. and Quinn, R. E. (1999). Diagnosing and changing organisational culture: based on the competing values framework. Addison-Wesley, Inc.

Case, S. S. and Srikatiana, P. (1998). Factors influencing TQM implementation in knowledge work environments: An integrative framework. Academy of Management, San Diego

Chang, F.S. and Wiebe, H.A. (1996). The Ideal Culture Profile for Total Quality Management: A Competing Values Perspective, Engineering Management Journal, 8 (2), 19-26

Choi, Y., Kim, J. Y. Yoo, T., (2016). A study on the effect of learning organisation readiness on employees' quality commitment: the moderating effect of leader-member exchange. Total Quality Management and Business Excellence, 27 (3-4), 325-338

Cunningham, C. E., Woodward, C. A., Shannon, H. S., MacIntosh, J., Lendrum, B., Rosenbloom, D. Brown, J. (2002). Readiness for organisational change: A longitudinal study of workplace, psychological and behavioural correlates. Journal of Occupational and Organisational Psychology. 75 (4), 377-392

Choi, M., and Ruona, W.E.A. (2011). Individual Readiness for Organisational Change and Its Implications for Human Resource and Organisation Development. Human Resource Development Review, 10 (1), 46-73

Dellana, S.A. and Hauser, R.D. (1999). Toward defining the quality culture. Engineering Management Journal, 11 (2), 11-15

Detert, J.R., Schroeder, R.G. and Mauriel, J.J. (2000). A Framework for Linking Culture and Improvement Initiatives in Organisations. Academy of Management Review, 25 (4), 850-863 
Djebarni, R. (1996). The impact of stress in site management effectiveness. Construction Management and Economics. 14 (4), 281-293.

Djebarni, R., Burnett S. and Richards, B. (2014). Research Methods for Business Students, Managers and Entrepreneurs, University of South Wales, 2014

Djebarni, R. and Al-Hyari, K. (2009). Exporting barriers and the internationalisation of manufacturing activities by SMEs in Jordan. ICSB World Conference Proceedings; Washington: 1-22.

Eby, L.T., Adams, D.M., Russell, J.E.A. Gaby, S.H. (2000). Perceptions of organisational readiness for change: factors related to employees' reactions to the implementation of team based selling. Human Relations. 53 (3), 419-442.

European Commission. (2013). Strategy paper 2007-2013 and National indicative programme 2007-2010 - Algeria. [Online], Available at:

(https://ec.europa.eu/europeaid/sites/devco/files/csp-nip-algeria-2007-2013_en.pdf

Eskildsen, J.K. and Edgeman, R. (2012). Continuous Relevance \& Responsibility: Integration of Sustainability \& Excellence via Innovation. Journal of Positive Management, 3 (1), 67-81.

Georgiev, S. and Ohtaki, S. (2016). Evolution and implementation of quality management practices in the manufacturing sector in Eastern Europe after the end of communism. International Journal of Quality Reliability Management, 33 (6), 804 - 829

Germain, R. and Spears, N. (1999). Quality management and its relationship with organizational context and design. International Journal of Quality \& Reliability Management, 16 (4), 371-91

Gimenez-Espin, J. A., Jiménez-Jiménez, D. and Martínez-Costa, M. (2012). Organisational culture for total quality management. Total Quality Management \& Business Excellence, 24 (5), 678-692

Goll, I. Rasheed, A. (1997). Rational Decision-Making and Firm Performance: The Moderating Role of Environment. Strategic Management Journal. 18, 583-591

Green, T. J. (2012). TQM and organisational culture: How do they link?. Total Quality Management \& Business Excellence, 23 (2), 141-157

Haffar, M., Al-Karaghouli, W. and Ghoneim, A. (2014). An empirical investigation of the influence of organizational culture on individual readiness for change in Syrian manufacturing organizations. Journal of Organizational Change Management, 27 (1), 5-22

Haffar, M. Al-Karaghouli, W. and Ghoneim, A. (2013). An analysis of the influence of organisational culture on TQM implementation in an era of global marketing: The case of Syrian manufacturing organisations. International Journal of Productivity and Quality Management, 11 (1), 96-115.

Hair, J.F., Black, W.C., Babin, B.J. and Anderson, R.E. (2010). Multivariate Data Analysis: With Readings, Pearson Education Inc., Upper Saddle River, NJ

Harvey, S. and Millett, B. (1999). OD, TQM AND BPR: A COMPARATIVE APPROACH. Australian Journal of Management and Organisational Behaviour, 2 (3), 30-42 
Holt, D. T., Armenakis, A.A, Field, H. S. and Harris, S. G. (2007). Readiness for Organisational Change: The Systematic Development of a Scale. The Journal of Applied Behavioural Science, 43 (2), 232-255

Herold, D.M., Fedor, D.B. Caldwell, S.D. (2007). Beyond change management: A multilevel investigation of contextual and personal influences on employees' commitment to change. Journal of Applied Psychology, 92 (4), 942-951.

Holbert, R. L. and Stephenson, M. T. (2002). Structural equation modeling in the communication sciences, 1995-2000. Human Communication Research, 28 (4), 531-551

Ingelsson, P., Eriksson, M. Lilja, J. (2012). Can selecting the right values help TQM implementation? A case study about organisational homogeneity at the Walt Disney Company. Total Quality Management and Business Excellence. 23 (1), 1-11.

Jones, R. A., Jimmieson, N. L. and Griffiths, A. (2005). The Impact of Organisational Culture and Reshaping Capabilities on Change Implementation Success: The Mediating Role of Readiness for Change. Journal of Management Studies, 42 (2), 361-386

Kirkham, L., Garza-Reyes, J. A., Kumar, V. and Antony, J. (2014). Prioritisation of operations improvement projects in the European manufacturing industry. International Journal of Production Research, 52 (18), 5323-5345.

Kasemi, K. (2009). The qualification requirements for quality management system in Algerian SMEs. Journal of Economic and Management Sciences. 9 (1), 165-178

Kline, P. (1994). An easy guide to factor analysis. New York, NY: Routledge.

Maheshwari, S and Vohra, V. (2015). Identifying critical HR practices impacting employee perception and commitment during organisational change. Journal of Organisational Change Management, 28 (5), $872-894$

McNabb, D.E. Sepic, F.T., (1995). Culture, Climate, and Total Quality Management: Measuring Readiness for Change, Public Productivity and Management. 18 (4), 369-385.

Meirovich, G., Galante, I, and Yaniv, K. M. (2006). Attitudes Towards TQM and the Communication Process between Managers and Subordinates. Journal of Applied Management and Entrepreneurship, 11 (1), 74-86

Neves, P. (2009). Readiness for change: Contributions for employee's level of individual change and turnover intentions. Journal of Change Management, 9 (2), 215-231

O'Reilly, C. A., III, and Chatman, J. A. (1996). Culture as social control: Corporations, cults, and commitment. In B. M. Staw and L. L. Cummings (Eds.), Research in organizational behavior, 18, 157-200. Greenwich, CT: JAI Press

Patterson MG, West MA, Shackleton VJ, Dawson JF, Lawthom R, Maitlis S. (2005). Validating the organizational climate measure: Links to managerial practices, productivity, and innovation. Journal of Organizational Behavior, 26 (4), 379-408. 
Psomas, E. and \& Antony, J. (2015). The effectiveness of the ISO 9001 quality management system and its influential critical factors in Greek manufacturing companies. International Journal of Production Research. 53 (7), 2089-2099

Prajogo, D. and McDermott, C. (2005). The relationship between total quality management practices and organisational culture", International Journal of Operations and Production Management,25 (11), 1101-1122

Sadikoqlu, E. and C. Zeihr. (2008). The impact of contextual factors on total quality management practices. Journal of Global Strategic Management, 4, 88-97

Samson, D. and Terziovski, M. (1999). The relationship between total quality management practices and operational performance. Journal of Operations Management, 17 (4), 393-409

Santos Vijande, M. L. and Álvarez González, L I. (2007). TQM and firms performance: an EFQM excellence model research based survey. International Journal of Business Science and Applied Management, 2 (2), 21-41

Schneider, A. P. Brief, R.A., and Guzzo, R. (1996). Creating a climate and culture for sustainable organisational change, Organisational Dynamics, 24 (4), 7 -19

Schneider, B. \& Barbera, K. M. (2014). The Oxford handbook of organisational climate and culture By (Eds.) New York, NY: Oxford University Press

Shea, C. and Howell, J. (1998). Organisational Antecedents to the Successful Implementation of Total Quality Management. Journal of Quality Management, 3 (1), 3-24

Shum, P., Bove, L. Auh, S., (2008). Employees' affective commitment to change: The key to successful CRM implementation. European Journal of Marketing. 42 (11-12), 1346 - 1371.

Sila, I. (2007). Examining the effects of contextual factors on TQM and performance through the lens of organisational theories: an empirical study. Journal of Operations Management. 25 (1), 83-109.

Smith, I. (2005). Achieving readiness for organisational change. Library Management, 26 (67), 408-412

Sohal, A.S. and Terzivski, M. (2000). TQM in Australian manufacturing: factors critical to success. International Journal of Quality \& Reliability Management, 17 (2), 158-167.

Sousa, R. and C.A. Voss. (2001). Quality management: universal or context dependent?”, Production and Operation Management, 10, 383-404

Srinivasan, A. and Kurey, B. (2014). Creating a culture of quality. Harvard Business Review, 92 (4). 23-25

Soltani, E., Lai P.G Gharneh, N.S. (2005). Breaking Through Barriers to TQM Effectiveness: Lack of Commitment of U er-Level Management. Total Quality Management. 16 (8/9), 1009-1021.

Tabachnick, B. G., Fidell, L. S. (2013). Using Multivariate Statistics , 6th ed. Boston : Pearson. 
Valmohammadi, C. Roshanzamir, S. (2015). The guidelines of improvement: Relations among organizational culture, TQM and performance. International Journal of Production Economics. 164 (1), 167-178.

Weeks, B., Helms, M. M. and Ettkin, L. P. (1995). Is your organisation ready for TQM? An assessment methodology. The TQM Magazine, 7 (5), 43-49

Weiner, B. J. (2009). A theory of organisational readiness for change. Implementation Science, 4 (67), 1-9

Whetten, D. A., Cameron, K. S. and Woods, M. (2000). Developing Management Skills for Europe, Pearson Education limited.

Yang, C., Lin, S., Chan, Y., Sheu, C. (2010). Mediated effect of environmental management on manufacturing competitiveness: An empirical study. Int. J. Production Economics. 123 (1), 210-220

Yu, T. and Wu, N. (2009). A Review of Study on the Competing Values Framework. Journal of Business and Management, 4 (7), 37-42

Zammuto, R. F., Gifford, B. and Goodman, E. A. (2000). Managerial ideologies, organisation culture and the outcomes of innovation: A competing values perspective, In Ashkana sy, N., Wilderom, C. And Peterson, M. (Eds.). The Handbook of Organisational Culture and Climate, Sage, Thousand Oaks, CA, 261-287

Zammuto, R. F. and O'Connor, E. (1992). Gaining advanced manufacturing technologies' benefits: the roles of organisation design and culture. Academy of Management Review, 17 (4), 701-728

Zhao, X., A. C. L. Yeung and T. S. Lee. (2004). Quality Management and Organizational Context in Selected Service Industries of China. Journal of Operations Management, 22, $575-587$

$\mathrm{Zu}$, X., Robbins, T.L. and Fredendall, L.D. (2010). Mapping the critical links between organisational culture and TQM/Six Sigma practices. International Journal of Production Economics, 123 (1), 86-106. 


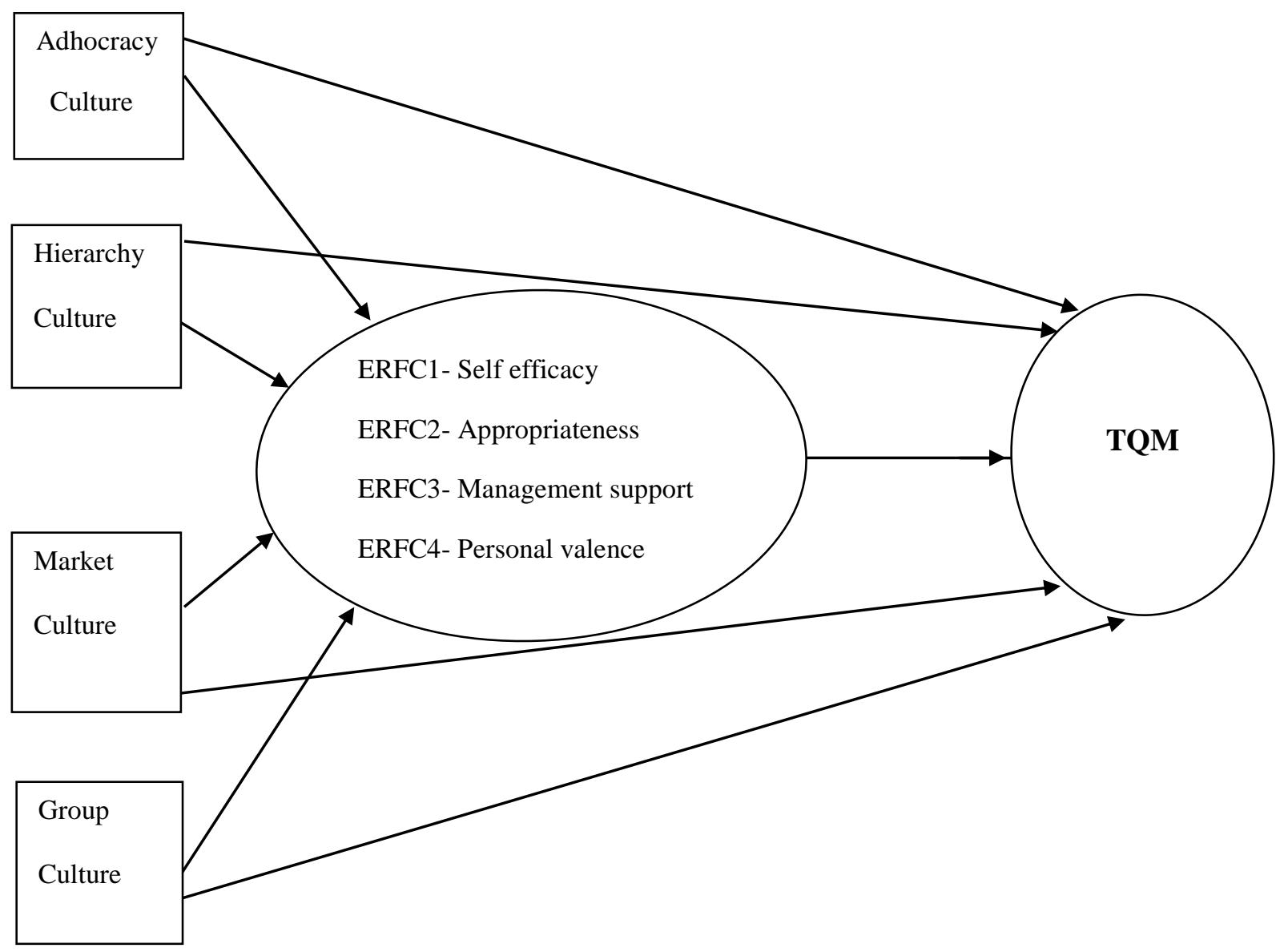

Figure 1. Proposed Conceptual Framework 
Table 1. ERFC components and their explanations

\begin{tabular}{|l|l|l|}
\hline Author(s) & Definitions & Construct nature/ dimensions \\
\hline al. (1993) & $\begin{array}{l}\text { "The cognitive precursor to the } \\
\text { behaviours of either resistance to, or } \\
\text { support of, a change effort. It is an } \\
\text { individual's "beliefs, attitudes, and } \\
\text { intentions regarding the extent to } \\
\text { which changes are needed and the } \\
\text { organisation's capacity to successfully } \\
\text { undertake those changes" (p. 681) }\end{array}$ & Unidimension \\
\hline $\begin{array}{l}\text { Cunningham } \\
\text { et al. (2002) }\end{array}$ & $\begin{array}{l}\text { "A demonstrable need for change, a } \\
\text { sense of one's ability to successfully } \\
\text { accomplish change (self-efficacy) and } \\
\text { an opportunity to participate in the } \\
\text { change process" (p.377). }\end{array}$ & \\
\hline Smith (2005) & $\begin{array}{l}\text { Employee's perceptions of the degree } \\
\text { to which their organisation has the } \\
\text { flexibility to achieve change, and the } \\
\text { extent to which they can actively and } \\
\text { genuinely participate in the process }\end{array}$ & Unidimension \\
\hline $\begin{array}{l}\text { Jones et al. } \\
\text { (2005) }\end{array}$ & $\begin{array}{l}\text { "The extent to which employees hold } \\
\text { positive views about the need for } \\
\text { organisational change (i.e. change } \\
\text { acceptance), as well as the extent to } \\
\text { which employees believe that such } \\
\text { changes are likely to have positive } \\
\text { implications for themselves and the } \\
\text { wider organisation" (p.362). }\end{array}$ & \\
\hline $\begin{array}{l}\text { Holt et } \\
\text { (2007) al. }\end{array}$ & $\begin{array}{l}\text { "ERFC is an individual's attitude } \\
\text { toward a particular change. It reflects } \\
\text { the extent to which an individual or } \\
\text { individuals are cognitively and } \\
\text { emotionally inclined to accept, } \\
\text { embrace, and adopt a particular plan } \\
\text { to purposefully alter the status quo" } \\
\text { (p.235). }\end{array}$ & Multidimensional construct \\
\hline
\end{tabular}


Table 2. ERFC dimensions and their explanations

\begin{tabular}{|l|l|}
\hline \multicolumn{1}{|c|}{ ERFC dimensions } & \multicolumn{1}{|c|}{ Explanations } \\
\hline ERFC- appropriateness & $\begin{array}{l}\text { ERFC- appropriateness represents the extent to which } \\
\text { organisational members believe that a particular change is } \\
\text { the sufficient solution and would be beneficial for the } \\
\text { organisation. }\end{array}$ \\
\hline ERFC- personal valence & $\begin{array}{l}\text { ERFC- personal valence reflects the extent to which } \\
\text { employees believe that the proposed change is beneficial to } \\
\text { organisational members }\end{array}$ \\
\hline $\begin{array}{l}\text { ERFC- change specific } \\
\text { efficacy }\end{array}$ & $\begin{array}{l}\text { ERFC- change specific relates to individuals' perception } \\
\text { that they are capable of implementing a proposed change } \\
\text { and feel confident that they would perform well and be } \\
\text { successful. }\end{array}$ \\
\hline ERFC- management support & $\begin{array}{l}\text { ERFC- management support reflects the extent to which } \\
\text { organisational members believe that the leaders support the } \\
\text { change }\end{array}$ \\
\hline
\end{tabular}


Table 3. Results of Factor and Reliability Analyses

\begin{tabular}{|c|c|c|c|c|c|c|}
\hline & $\begin{array}{l}\text { No. of } \\
\text { items }\end{array}$ & Factor & adings & Composite Reliability (CR) & $\%$ variance & Cronbach \\
\hline Group culture & 6 & Gr1 & .845 & 0.82 & 63.060 & .780 \\
\hline (group) & & $\mathrm{Gr} 2$ & .797 & & & \\
\hline & & Gr3 & 493 & & & \\
\hline & & Gr4 & .816 & & & \\
\hline & & Gr5 & .833 & & & \\
\hline & & Gr6 & .977 & & & \\
\hline Adhocracy & 6 & Adh1 & .646 & 0.85 & 58.339 & .772 \\
\hline culture & & Adh2 & .748 & & & \\
\hline & & Adh3 & .709 & & & \\
\hline & & Adh4 & .771 & & & \\
\hline & & Adh5 & .845 & & & \\
\hline & & Adh6 & .653 & & & \\
\hline Hierarchy culture & 6 & HIRa1 & 0.923 & 0.83 & 54.490 & .806 \\
\hline (hierarchy) & & HIRa2 & .798 & & & \\
\hline & & HIRa3 & .626 & & & \\
\hline & & HIRa4 & .794 & & & \\
\hline & & HIRa5 & .641 & & & \\
\hline & & HIRa6 & .467 & & & \\
\hline Market culture & 6 & Mar1 & .716 & 0.94 & 61.365 & .858 \\
\hline (market) & & Mar2 & .557 & & & \\
\hline & & Mar3 & .813 & & & \\
\hline & & Mar4 & .803 & & & \\
\hline & & MAr5 & 0.961 & & & \\
\hline & & Mar6 & .774 & & & \\
\hline Leadership & 7 & Led1 & .819 & 0.82 & 51.160 & .722 \\
\hline & & led2 & .441 & & & \\
\hline & & Led3 & .597 & & & \\
\hline & & led4 & 819 & & & \\
\hline & & Led5 & .898 & & & \\
\hline & & Led6 & .394 & & & \\
\hline & & Led7 & .871 & & & \\
\hline Customer Focus & 7 & Cf1 & .898 & 0.86 & 53.553 & .707 \\
\hline & & $\mathrm{Cf} 2$ & .535 & & & \\
\hline & & Cf3 & .650 & & & \\
\hline & & Cf4 & .891 & & & \\
\hline & & Cf5 & .754 & & & \\
\hline & & Cf6 & .795 & & & \\
\hline & & Cf7 & .562 & & & \\
\hline People & 9 & $\mathrm{Hr} 1$ & .741 & 0.88 & 51.119 & .776 \\
\hline Management & & $\mathrm{Hr} 2$ & .617 & & & \\
\hline & & $\mathrm{Hr} 3$ & .777 & & & \\
\hline & & $\mathrm{Hr} 4$ & .553 & & & \\
\hline & & $\mathrm{Hr} 5$ & .827 & & & \\
\hline & & $\mathrm{hr} 6$ & .682 & & & \\
\hline & & Hr7 & .686 & & & \\
\hline & & $\mathrm{Hr} 8$ & .707 & & & \\
\hline & & $\mathrm{Hr} 9$ & .801 & & & \\
\hline Strategic Planning & 7 & St1 & .935 & 0.77 & 50.240 & .743 \\
\hline & & St2 & .878 & & & \\
\hline & & St3 & .336 & & & \\
\hline & & St4 & .890 & & & \\
\hline & & St5 & .820 & & & \\
\hline & & St6 & .558 & & & \\
\hline & & St7 & .541 & & & \\
\hline Process & 6 & Pm1 & .714 & 0.84 & 57.359 & .802 \\
\hline Management & & Pm2 & .826 & & & \\
\hline & & Pm3 & .780 & & & \\
\hline & & Pm4 & .708 & & & \\
\hline & & Pm5 & .767 & & & \\
\hline & & Pm6 & .743 & & & \\
\hline
\end{tabular}




\begin{tabular}{|c|c|c|c|c|c|c|}
\hline \multirow{6}{*}{$\begin{array}{l}\text { Information and } \\
\text { Analysis }\end{array}$} & \multirow[t]{6}{*}{6} & Im1 & .757 & \multirow[t]{6}{*}{0.79} & \multirow[t]{6}{*}{57.359} & \multirow[t]{6}{*}{.762} \\
\hline & & $\operatorname{Im} 2$ & .625 & & & \\
\hline & & $\operatorname{Im} 3$ & .743 & & & \\
\hline & & $\operatorname{Im} 4$ & .391 & & & \\
\hline & & $\operatorname{Im} 5$ & .803 & & & \\
\hline & & Im6 & .782 & & & \\
\hline \multirow{6}{*}{$\begin{array}{l}\text { Total Quality } \\
\text { Management } \\
\text { (TQM) }\end{array}$} & \multirow[t]{6}{*}{6} & Tqm1 & .777 & \multirow[t]{6}{*}{0.90} & \multirow[t]{6}{*}{62.005} & \multirow[t]{6}{*}{.876} \\
\hline & & Tqm2 & .836 & & & \\
\hline & & Tqm3 & .812 & & & \\
\hline & & Tqm4 & .621 & & & \\
\hline & & Tqm5 & .759 & & & \\
\hline & & Tqm6 & .765 & & & \\
\hline \multirow{4}{*}{$\begin{array}{l}\text { ERFC- Personally } \\
\text { Beneficial }\end{array}$} & \multirow[t]{4}{*}{4} & Pb1 & .716 & \multirow[t]{4}{*}{0.87} & \multirow[t]{4}{*}{58.325} & \multirow[t]{4}{*}{.752} \\
\hline & & $\mathrm{Pb} 2$ & .854 & & & \\
\hline & & $\mathrm{Pb} 3$ & .594 & & & \\
\hline & & $\mathrm{Pb} 4$ & .859 & & & \\
\hline \multirow{6}{*}{$\begin{array}{c}\text { ERFC- } \\
\text { Management } \\
\text { Support }\end{array}$} & \multirow[t]{6}{*}{6} & Ms1 & .927 & \multirow[t]{6}{*}{0.92} & \multirow[t]{6}{*}{65.883} & \multirow[t]{6}{*}{.889} \\
\hline & & Ms2 & .830 & & & \\
\hline & & Ms3 & .860 & & & \\
\hline & & Ms4 & .763 & & & \\
\hline & & Ms5 & .604 & & & \\
\hline & & Ms6 & .848 & & & \\
\hline \multirow{6}{*}{$\begin{array}{c}\text { ERFC-Self } \\
\text { efficacy }\end{array}$} & \multirow[t]{6}{*}{6} & Se1 & .836 & \multirow[t]{6}{*}{0.94} & \multirow[t]{6}{*}{63.263} & \multirow[t]{6}{*}{.883} \\
\hline & & $\mathrm{Se} 2$ & .826 & & & \\
\hline & & $\mathrm{Se} 3$ & .878 & & & \\
\hline & & $\mathrm{Se} 4$ & .758 & & & \\
\hline & & Se5 & .626 & & & \\
\hline & & Se6 & .735 & & & \\
\hline \multirow{8}{*}{$\begin{array}{c}\text { ERFC- } \\
\text { Appropriateness }\end{array}$} & \multirow[t]{8}{*}{8} & Ap1 & .744 & \multirow[t]{8}{*}{0.79} & 50.583 & .830 \\
\hline & & Ap2 & .690 & & & \\
\hline & & Ap3 & .765 & & & \\
\hline & & Ap4 & .699 & & & \\
\hline & & Ap5 & .806 & & & \\
\hline & & Ap6 & .460 & & & \\
\hline & & Ap7 & .777 & & & \\
\hline & & Ap8 & .655 & & & \\
\hline
\end{tabular}


Table 4. The Mean Score of OC types, TQM and ERFC components

\begin{tabular}{|l|l|l|}
\hline & Mean & SD \\
\hline Group culture & 2.26 & .76 \\
\hline Adhocracy culture & 2.30 & .85 \\
\hline Hierarchy culture & 2.83 & .91 \\
\hline Market culture & 2.86 & .83 \\
\hline ERFC- Personal valence & 2.57 & .76 \\
\hline ERFC- Management Support & 2.70 & .89 \\
\hline ERFC- Self-efficacy & 2.61 & .88 \\
\hline ERFC- Appropriateness & 2.69 & .92 \\
\hline TQM & & \\
\hline
\end{tabular}


Table 5. Summary of the Results of the Regression Models

\begin{tabular}{|c|c|c|c|c|c|c|c|}
\hline & & \multicolumn{2}{|c|}{$\begin{array}{l}\text { Unstandardized } \\
\text { Coefficients }\end{array}$} & \multirow{2}{*}{$\begin{array}{l}\text { Standardised } \\
\text { Coefficients } \\
\text { Beta }\end{array}$} & \multirow[t]{2}{*}{ T- test } & \multirow[t]{2}{*}{ Sig } & $\begin{array}{l}\text { Model } \\
\text { Summery }\end{array}$ \\
\hline & & B & S.E & & & & \multirow{5}{*}{$\begin{array}{l}\text { Sig of } F=.000 \\
\text { Adjusted } R^{2}= \\
.261\end{array}$} \\
\hline Model 1: & group & .174 & .048 & .301 & 3.602 & .000 & \\
\hline \multirow{3}{*}{$\begin{array}{l}\text { Dependent } \\
\text { Variable: }\end{array}$} & adhocracy & .145 & .049 & .248 & 2.959 & .003 & \\
\hline & market & .016 & .053 & .029 & .294 & .769 & \\
\hline & hierarchy & -.112 & .062 & -.170 & -1.792 & .075 & \\
\hline Model 2: & group & .220 & .038 & .378 & 5.817 & .000 & \multirow{4}{*}{$\begin{array}{l}\text { Sig of } F=.000 \\
\text { Adjusted } \mathrm{R}^{2}= \\
.226\end{array}$} \\
\hline Dependent & adhocracy & .111 & .038 & .191 & 2.946 & .004 & \\
\hline \multirow{2}{*}{$\begin{array}{l}\text { Personal } \\
\text { valence }\end{array}$} & market & -.021 & .051 & -.036 & -.409 & .683 & \\
\hline & hierarchy & -.046 & .051 & -.079 & -.898 & .370 & \\
\hline Model 3: & group & .163 & .042 & .267 & 3.890 & .000 & \multirow{5}{*}{$\begin{array}{l}\text { Sig of } F=.000 \\
\text { Adjusted } R^{2}=\end{array}$} \\
\hline Dependent & adhocracy & 101 & 042 & 164 & 2397 & 017 & \\
\hline Variable: & & & & & & & \\
\hline \multirow{2}{*}{ Self-Efficacy } & market & -.075 & .057 & -.123 & -1.328 & .186 & \\
\hline & hierarchy & .011 & .057 & .018 & .198 & .844 & \\
\hline Model 4: & group & .081 & .041 & .129 & 1.979 & .049 & \multirow{4}{*}{$\begin{array}{l}\text { Sig of } F=.000 \\
\text { Adjusted } \mathrm{R}^{2}= \\
.222\end{array}$} \\
\hline Dependent & adhocracy & .243 & .041 & .386 & 5.929 & .000 & \\
\hline \multirow{2}{*}{ Appropriateness } & market & -.085 & .056 & -.135 & -1.536 & .036 & \\
\hline & hierarchy & -.010 & .055 & -.016 & -.178 & .126 & \\
\hline Model 5: & group & .099 & .046 & .151 & 2.152 & .033 & \multirow{4}{*}{$\begin{array}{l}\text { Sig of } F=.000 \\
\text { Adjusted } R^{2}= \\
.206\end{array}$} \\
\hline Dependent & adhocracy & .126 & .046 & .192 & 2.736 & .000 & \\
\hline \multirow{2}{*}{$\begin{array}{l}\text { Management } \\
\text { Support }\end{array}$} & market & .014 & .062 & .022 & .228 & .707 & \\
\hline & hierarchy & -.089 & .062 & -.136 & -1.436 & .820 & \\
\hline \multirow{4}{*}{$\begin{array}{l}\text { Dependent } \\
\text { Variable: } \\
\text { TQM }\end{array}$} & $\begin{array}{l}\text { personal } \\
\text { valence }\end{array}$ & .162 & .041 & .239 & 3.950 & .000 & \multirow{4}{*}{$\begin{array}{l}\text { Sig of } F=.000 \\
\text { Adjusted } \mathrm{R}^{2}= \\
.332\end{array}$} \\
\hline & self-efficacy & .320 & .045 & .431 & 7.128 & .000 & \\
\hline & $\begin{array}{l}\text { management } \\
\text { support }\end{array}$ & -.077 & .067 & -.129 & -1.149 & .252 & \\
\hline & appropriateness & -.024 & .074 & -.036 & -.324 & .746 & \\
\hline
\end{tabular}




\begin{tabular}{|c|c|c|c|c|c|c|c|}
\hline $\begin{array}{l}\text { Model 7: } \\
\text { Dependent } \\
\text { Variable: } \\
\text { TQM }\end{array}$ & group & .139 & .048 & .241 & 2.887 & .004 & \multirow{6}{*}{$\begin{array}{l}\text { Sig of } F=.000 \\
\text { Adjusted } \mathrm{R}^{2=} \\
.348 .\end{array}$} \\
\hline \multirow{5}{*}{$\begin{array}{l}\text { Dependent } \\
\text { Variable: } \\
\text { TQM }\end{array}$} & adhocracy & .104 & .049 & .178 & 2.103 & .037 & \\
\hline & & & 052 & 015 & 150 & 874 & \\
\hline & & & & & & & \\
\hline & hierarchy & -.115 & .061 & -.176 & -1.905 & .058 & \\
\hline & $\begin{array}{l}\text { personal } \\
\text { valence }\end{array}$ & .125 & .037 & .230 & 3.378 & .001 & \\
\hline \multirow{5}{*}{$\begin{array}{l}\text { Model 8: } \\
\text { Dependent } \\
\text { Variable: TQM }\end{array}$} & group & .114 & .048 & .197 & 2.364 & .019 & \multirow{5}{*}{$\begin{array}{l}\text { Sig of } F=.000 \\
\text { Adjusted } \mathrm{R}^{2}= \\
.354 \text {. }\end{array}$} \\
\hline & adhocracy & .105 & .048 & .180 & 2.198 & .029 & \\
\hline & market & .017 & .051 & .031 & .334 & .739 & \\
\hline & hierarch & -.121 & .060 & -.184 & -2.026 & .044 & \\
\hline & self-efficacy & .155 & .036 & .294 & 4.321 & .000 & \\
\hline
\end{tabular}

